\title{
Wat is die reg en die vryheid van die eksegeet?
}

\author{
BJ Engelbrecht
}

\section{Abstract \\ What is the right and freedom of the exegete?}

The themes centring around Scripture, $\mathrm{i}$ e the 'right' way or ways to interpret it, its usage in the church and its authority is very much in discussion in theology today. It is no wonder because the maxim sola Scriptura is so basic to protestant theology that it is called the principium fundamentale vel cognoscendi. The question of the freedom of the exegete of the Bible, arises from the very nature of the Bible itself. Protestantism confesses that the Bible is God's Word to man and yet this Word comes to us in the form of (fallible?) human words written through many ages and sometimes receiving more than one redaction. This situation is further complicated: (a) By the fact that we have no 'original text' of the Bible. From this fact follows the task for the exegete to reconstruct by scientific means the most probable, reliable 'original' text; (b) By the fact that between the present Bible-word and the original Word of God to man, there exists at least two hiatuses, i e between the writing down of the word of the 'prophet' or 'apostle' and the specific situation wherein it was spoken and heard. The truth of words does not lie in themselves, but often in the (psychologic, literary and historic) situation in which they were spoken. The historic and literary criticism tries to bridge this gap. The second hiatus is between the 'prophet' and the revelation, the Word of God Himself. The theological criticism tries to bridge this gap and amongst others to give due weight to the fact that the Bible, human in form and content, is simultaneously Word of God. This article proceeds to discuss the various phases in the exegetic process and their connection with (and limitation by - if any) the church-dogma.

\section{INLEIDING}

In 1962 het die bekende Geyser-saak plaasgevind. Aan my as dogmatikus van Nederduitsch Hervormde Kerk aan die Universiteit van Pretoria, is toe gevra om onder andere oor bostaande onderwerp advies aan die Eerwaarde Algemene Kommissie uit te bring. Die rede daarvoor was kortliks dat prof Geyser aangevoer het dat dit 'n reformatoriese beginsel is dat die Skrif as norma normans bokant die kerklike belydenis as norma normata staan, en dat die eksegeet bygevolg nie in 
sy arbeid deur die kerklike belydenis aan bande gelê word nie - nie wat betref die eksegetiese metode nie, en ook nie ten opsigte van sy resultate nie. Die aanklag teen prof Geyser was juis dat hy in sy uitleg van Filippense 2:6-9, terwyl hy nog ander sogenaamde dogmatiese bewysplekke soos die Johannes-proloog daarby betrek het as steun vir sy standpunt, in stryd met die kerklike belydenis ' $n$ subordinatiaanse en selfs Ariaanse Christologie in sy klasse 'verkondig' het.

Soos binne ' $n$ reformatoriese konteks te verwagte is, sal die onderwerp van die Heilige Skrif altyd in die belangstellingsveld staan. Veral in die afgelope dekade het daar onder andere as gevolg van die beskouings van James Barr en rondom die begrip 'struktuur' (waarvan Nida onder andere sê dat dit miskien die belangrikste begrip in die huidige diskussie rondom die Skrif is) weer nuwe belangstelling en diskussies ontstaan rondom die met-mekaar-saamhangende temas van Skrifbeskouing en Skrifgebruik. In die subgroepe èn in die gesamentlike vergaderings van die Tussenkerklike Kommissie van die drie Afrikaanse Susterkerke is alreeds baie ure aan dié onderwerp bestee.

Ek het dit daarom goed gedink om hierdie advies-stuk uit 1962 te publiseer in die bundel wat aan prof PS Dreyer met sy aftrede as filosofie-professor aan die Universiteit van Pretoria opgedra is. Sy pad was vir baie jare ' $n$ pad wat nooit ver van die middelpunt van die Nederduitsch Hervormde Kerk geloop het nie.

Ek het die genoemde advies feitlik onveranderd gelaat. By die meeste aanhalings het ek probeer om die bron te vermeld wat destyds in my mondelinge getuienis nie nodig was nie. Trouens, indien prof Geyser dit sou versoek het, sou ek maklik dit kon verstrek het vir die stuk wat ek binne drie dae, so twee dae tevore opgestel het. Ná byna 'n kwart eeu, was die opspoor van my bronne baie moeiliker. Ek publiseer hierdie advies eintlik as 'n historiese dokument van hoe ons destyds oor die onderhawige probleem gevoel en gedink het. Miskien kan dit selfs ' $n$ bydrae in die huidige diskussie lewer.

\section{DIE NOODSAAKLIKHEID VAN EKSEGETIESE ARBEID IN DIE PROTESTANTSE TEOLOGIE}

Beide Rome en die Reformasie wil formeel uitgaan van dit wat God geopenbaar het as die waarheid, dié waarheid waarvolgens hulle in gehoorsaamheid hulle geloof en lewe wil inrig en waarop hulle hulle hoop wil bou. In sekere sin wil albei formeel uitgaan van die Woord van God. 
Die verskil kom egter daarby wanneer gevra word:

- Waar vind ons die openbaring, die Woord van God?

- Waaraan ontleen daardie Woord sy gesag?

\subsection{Rome antwoord:}

(a) 'Die Katolieke Kerk weet wat God geopenbaar het uit die Heilige Skrif en die oorlewering.' 'Die Heilige Skrif alleen bevat nie alles wat God geopenbaar het nie, daarom is die oorlewering noodsaaklik.'

Daar is dus twee openbaringsbronne: Die Heilige Skrif en die oorlewering, die tradisie. Soms kan 'n geloofswaarheid vir eeue soos ' $n$ saadkiem in die oorlewering verborge lê en dan byvoorbeeld deur die vrome opinie groei tot 'n boom wat dan deur die kerklike leeramp onfeilbaar' $n$ vaste vorm kry.

(b) Die Rooms-Katolieke Kerk beskik ook oor Skrif en Tradisie.

Eerstens: 'Deur die bystand van die Heilige Gees' het die kerk deur die ononderbroke opeenvolging van tye en persone in die leeramp en gemeente die waarheid van hierdie twee bronne altyd onvervalsd bewaar, en onfeilbaar uitgelê.

Tweedens: 'Die Pous en die biskoppe verkondig die leer van die Katolieke Kerk.' 'Die Kerk leer watter boeke tot die Heilige Skrif behoort' (bostaande sitate uit: Katolieke Katechismus 1941: 4 en 5) en bepaal ook die Tradisie. Beide omvang en inhoud word deur die Kerk onfeilbaar bepaal en gewaarborg. Die gesag van Skrif en tradisie hang af van die oordeel van die Kerk. Indien ' $n$ waarheid eers eenkeer formeel deur die Kerk onfeilbaar ex cathedra gedefinieer is, is dit onveranderlik (Denzinger 1953: I, f; II, c; III, f).

Hier in Densinger lees ons onder andere: 'Fons revelationis scriptus sunt libri canonici utriusque Testamenti, quorum habetur versio authentica in Vulgata ... Fons revelationis alter est tradition ecclesiastica (IS I, f). Ecclesia habet jure divino jus et officium doctrinam revelatam custodiendi et exponendi, et in hoc munere est infallabilis per inhabitantem Spiritum Sanctum quo juvante depositum fidei inviolabiliter servat et infalabiliter explicat, neque unquam erravit (IS II, c). Romanus pontifex quando 'ex cathedra loquitur' hinc est supremus Doctor Eccle- 
siae cuius definita sententia irretractabilis est .... Romanus Pontifex nunquam erravit in rebus fidei aut morum (IS III, $\mathrm{f}$ ).

Hoewel daar in die jongste tyd skynbaar 'n mate van vryheid onder die Rooms-Katolieke eksegete (beide van Skrif en Tradisie) bestaan, is diě vryheid alleen maar 'n metodiese vryheid, terwyl die resultaat al vantevore vas staan, vasgevang en bepaal deur die vaste lyne van die onveranderlike dogma. Vanuit die Skrif en Tradisie bestaan daar geen appěl nie; die resultaat is alreeds bepaal. Omdat die dogma onveranderlik is, bestaan daar byvoorbeeld geen moontlikheid van 'n gravamen met 'n beroep op die Skrif nie.

Op die twee vrae: (a) Waar vind ons die openbaring, die Woord van God? en (b) waaraan ontleen daardie Woord sy gesag? antwoord die

\subsection{Protestantisme:}

(a) Ons vind die Woord van God alleen in die Skrif. Die formele beginsel van die Hervorming is sola Scriptura, dit wil sê die Skrif alleen is die bron van ons kennis aangaande God en daarom die enigste norm vir geloof en lewe. Ons kan dit nie prinsipieel begrond of bewys nie, want anders sal ons bo die Skrif staan om te bewys dat die Skrif alleen die Woord van God is. Ons kan dit alleen maar glo uit en op grond van die Skrif self dat die Skrif alleen die enigste bron van ons kennis en norm van ons geloof is.

(b) Die Skrif ontleen ook nie sy gesag en geloofwaardigheid aan die oordeel van die Kerk nie, maar as Woord van God dra dit sy gesag, geloofwaardigheid en genoegsaamheid in sigself. As Woord van God ontleen dit sy gesag aan God self, aan God die Heilige Gees. Die getuienis van die Heilige Gees is nodig om volle gesag aan die Skrif te verleen.

Gedurigdeur klink die refrein in die reformatoriese belydenisse en geskrifte van 'Woord-en-Gees'.

(c) En hierin lê een van die kernpunte van die probleem van die reformatoriese eksegese van die Heilige Skrif opgesluit:

Eerstens: Die Heilige Skrif is vry van die binding aan die tradisionalisme van die Roomse Kerk. Die resultaat van Skrifondersoek staan nie vantevore al vas, gebind deur die gesag, tradisie en dogma van die Kerk nie. Daar bestaan nie meer in dieselfde sin as by Rome ' $n$ offisieel-kerklike eksegese nie. Die vraag is nou, as ons van elders ' $n$ beeld mag ontleen: Wat is die verband, die sinkopee, van die tweeslag- 
maat: Skrif en Kerk? Kan die Kerk metode en resultaat van die uitleg van die Skrif (die Skrif wat nie in verband met sy gesag afhanklik van die Kerk is nie) bepaal? 'n Faset van dié vraag is: Die Reformasie het in haar eksegese die formele grammatika opgeneem om haarself los te worstel van die tradisionalisme van die Roomse Kerk èn deur terug te keer na die bronne toe, ad fontes. In hoeverre kan die Kerk nou iets sê oor hierdie objektiewe, formele grammatika?

Tweedens: Die letter maak dood, die Gees maak lewendig: Daarom: Woord èn Gees. Die vraag is nou: Watter rol speel die Heilige Gees in die uitleg van die Skrif waarin die Woord van God volkomelik bevat is? In hierdie verband worstel Luther vir 'n nuwe spraak en nuwe denkvorme, 'ein seltsame sprache und newe Grammatica'. Hy sê dat God wil, omdat ons geestelike mense is, ook dat ons 'ander und newe gedanken verstand sinne haben und kein ding ansehen nach der vernunft, wie es für der welt steht sondern wie es für seinen augen ist...' (WA 34/2: $480 \mathrm{v}$ ).

Die vraag is nou in hoeverre hierdie, 'neue Grammatica', die formele grammatika by die uitleg van die Skrif mag, kan of moet beïnvloed? Met ander woorde, die vraag is: Wat is die verband tussen die Heilige Gees en Skrifuitleg indien Woord en Gees so nou met mekaar verbonde is, indien die Woord nie maar sommer enige woord is nie, maar Woord van God?

Bogenoemde twee vrae kan in één vraag saamgevat word: Wat is die verband tussen Kerk, Skrif en Heilige Gees en watter invloed mag of moet dit hê op die uitleg van die Skrif?

Ons het hier alreeds sekere probleme aangesny wat spruit uit die reformatoriese reël van sola Scriptura. In elk geval is een ding duidelik: Indien die Reformasie die Skrif alleen as die enigste bron van ons 'teologiese' kennis en die enigste norm vir ons geloof en lewe stel, dan is die praktyk van die eksegese (die uitleg van die Skrif) en die vrae in verband met die aard en taak van die eksegese van wesenlike belang.

\section{WAT IS EKSEGESE - NODIGHEID EN STRUKTUUR}

3.1 Die feit dat eksegese nodig is, hang saam met die karakter van die Heilige Skrif, naamlik dat dit geen towerboek is wat kant en klaar uit die hemel tot ons gekom het nie. Die Heilige Skrif is, 
hoewel dit die Woord van God volkomelik bevat, 'n menslike boek en dit wel in dubbele sin:

- Die Woord van God is deur mense gehoor, neergeskryf en literêr bewerk en as sodanig het dit 'n geskiedenis.

- Dit word gelees deur mense in wie se geskiedenis dit sy bestaan voer.

Alreeds net hierdie laaste feit, naamlik dat die Heilige Skrif deur mense gelees word, maak eksegese nodig. Al die mense lees nie eenders nie en een-en-dieselfde gedeelte word deur verskillende mense só gelees dat die inhoude in teenspraak met mekaar kan staan. Die eerste vraag is nou: Wat staan daar presies geskryf? Dit is dus ook die eerste vraag en taak van die eksegese.

Ook die eerste feit, naamlik dat die Woord van God deur mense gehoor, vertolk en neergeskryf is en dat die hoor en optekening en literêre bewerking oor eeue strek, vra eksegetiese arbeid. Ons noem slegs enkele dinge wat uit hierdie feit voortvloei en wat die taak van die eksegese bepaal:

Eerstens het ons nie die oorspronklike manuskrip van die profeet of apostel nie. Ons het alleen maar 'n afskrif wat dikwels ook literêr bewerk is. Tussen die 'oorspronklike' manuskrip en die afskrifte lê 'n ruimte, dikwels van baie eeue. Daarom moet ons eers die teks probeer vasstel deur die afskrifte te bestudeer, hulle herkoms en betroubaarheid bepaal, ensovoorts.

Dan is daar ook dikwels 'n ruimte tussen die optekening en die woord wat deur die profeet of apostel gespreek is in ' $n$ bepaalde situasie. Hier sal die historiese en literêre kritiek sy arbeid moet verrig om die waarheid en sin van hierdie woord te bepaal deur die verhouding van woord en historiese en psigologiese situasie na te gaan. Tereg is opgemerk dat die 'waarheid en waarde van die Gods Woord nie soseer in die oorgelewerde woorde self lê nie, as in die verhouding van hierdie woorde tot die mens en toestande waarin hierdie woorde vir die eerste keer gespreek is. Vandaar dat die Godswoorde losgemaak van hulle oorspronklike omgewing, mekaar skynbaar weerspreek' (Van Selms 1951: 58 èn Van Selms 1952: 122-123). Deur genoemde arbeid en deur hierdie feit dat die Gods Woord in 'n bepaalde situasie gespreek is en die waarheid van woord van situasie afhang, is tegelykertyd die grens aangedui van die tekskritiese en grammatikale arbeid van 
die eksegese sonder om daarmee te sê dat laasgenoemde nie ook uiters belangrik is nie.

Derdens is daar die ruimte tussen die woord wat die profeet gehoor en gespreek het en die openbaring self, die Gods Woord wat tot hom gekom het. Die teologiese kritiek probeer om hierdie ruimte te oorbrug en vanaf die vertolking van die openbaring terug te gaan na die openbaring, na die Gods Woord self. Uiteindelik gaan dit tog daarom: Wat sê God in hierdie gedeelte? (Oor hierdie drie ruimtes en hulle oorbrugging, kyk Van Selms 1952: $117 \mathrm{vv})$.

En hiermee het ons weer uitgekom by dié vraag wat ons gestel het in verband met die onderwerp: Woord en Gees.

Die vraag kom naamlik hieruit voort: Ons gee toe dat ons die Woord van God alleen in die vorm van gebroke woord van mense het; en tog is dit Gods Woord. Die vraag is: In hoeverre moet die feit dat hierdie boek Gods Woord is, ons eksegese bepaal? Of anders gestel, in hoeverre speel die leiding van die heilige Gees by die eksegese ' $n$ rol?

As gedeeltelike antwoord wil ons hier stel: Die eksegeet sal, watter metode hy ook al gebruik, van die veronderstelling moet uitgaan dat hy hier met Gods Woord te doen het, en daarom sal die eksegeet gedurigdeur biddend moet vra om die leiding van die Heilige Gees met die vaste vertroue op die belofte dat die Gees hom in alle waarheid sal lei. Dit sal die eksegeet moet doen sonder om in sy metodiese veronderstellings te vergeet dat hierdie Godswoord alleen in gebroke mensewoord tot ons gekom het en kom. Laasgenoemde sal die eksegeet daarvan bewaar dat hy nie onkrities die huidige geskrewe woord met die profete-woord as sodanig en dan direk met die Godswoord vereenselwig nie. Omdat die Bybel geen orakelboek is nie, sal hy in hierdie verband ook besef dat sy grammatikaal-literêr-kritiese en historiese metode geen orakelmetode is wat uit die hemel neergedaal het nie; as dit enige diens wil lewer, moet dit menslike metode bly.

Maar die eerste veronderstelling, naamlik dat ons hier met Gods Woord te doen het, al is die vorm daarvan menslik, sal die eksegeet weer daarvan bewaar om sy teologiese gesigspunt uit die oog te verloor. Per slot van rekening bedryf hy tog teologie ten dienste van die prediking, die prediking nie van 'n mensewoord nie, maar van Gods Woord. Hierdeur sal die eksegeet besef dat ' $n$ profeet nooit buite die geloof om herken kan word 
nie en dat die drie genoemde ruimtes tussen die Bybel, die profetewoord en Gods Woord alleen deur God self, deur die Heilige Gees in die geloof oorbrug kan word. Daarmee is ons insiens nie 'n grens gestel aan die taak van die eksegeet nie, maar wel aan die historiese en grammatikaal-literêre metode. Deur genoemde feit sal hy agterkom dat hy behalwe van die historiese en grammatikale metode, ook van ander metodes gebruik sal moet maak om die Skrif te verstaan - met ander woorde hy sal agterkom dat eksegese 'n teologiese wetenskap is.

Hierdie dubbele taak van die eksegese hang saam met die eie aard van die Bybel self. Hieroor het niemand myns insiens aangrypender geskryf as een van my leermeesters, Gerardus van der Leeuw nie (kyk Van der Leeuw 1958: 102; vgl ook Van der Leeuw 1954, veral bl 6).

De Bijbel is een natuurboek, vol driften, vol van eten en drinken, vrijen en trouwen, doodslaan en hoereeren, bloed-en rasbesef. Hij is een cultuurboek, vol van kunst en wetenschap, akkerbouw en veeteelt, oorlog en vrede, politiek en levenswijsheid. Maar hij is geen humanistisch boek. Hij is een goddelijk boek. Geen idealistisch boek. Maar een realistisch boek. Hij weet van een oordeelenden God, wiens weg dwars door onze natuur en cultuur heengaat. Geboren, jawel - maar: in zonde. Drift, zeker - maar: geneigd tot alle kwaad. Arbeidend, natuurlijk maar: onbekwaam tot eenig goed.

3.2 Die probleem van die eksegese is dat daar geen enkele metode is wat in die geskiedenis gegee is en wat onfeilbaar en dus dié eksegetiese metode is nie.

Dit blyk alreeds uit die begin van die eksegetiese arbeid in die Christendom wat miskien ook sy wortels het in die tipes van eksegese in die Nuwe Testament self. Die skool van Alexandrië (bv Clemens, Origines) het 'n allegoriese metode van eksegese voorgestaan terwyl die Antiocheense skool (Joh Chrysostemos en Theodorus van Mopsuesta) weer as eksegese gesien het 'n meer letterlike verklaring van die Bybel. Augustinus en Hiëronimus het probeer om die twee metodes te kombineer, terwyl Petrus Lombardus, Alexander van Halles en Thomas Aquinas 'n viervoudige metode voorgestaan het, naamlik - letterlike, figuurlik, moreel en anagogies.

Dit is hier onmoontlik om in hierdie bestek 'n geskiedenis van 
die eksegetiese metodes te gee, maar die volgende kan gekonstateer word:

Eerstens dat daar geen onfeilbare eksegetiese metode is nie. Gedurigdeur is een rigting gekorrigeer deur ' $n$ ander. So het in die vorige eeu byvoorbeeld Vilmarus sterk te velde getrek teen die filologies-grammatikale en histories-literêre metode se alleenheerskappy in die teologie en gepleit vir'n eksegese wat tot die saak self, naamlik die prediking van die geskrifte en hulle openbaringsgehalte, wil deurdring. So wil byvoorbeeld R Bultmann die metode van Schleiermacher en Dilthey korrigeer met die regte eksegese, naamlik die eksistensiële interpretasie van die Nuwe Testament en so wil byvoorbeeld Bleeker die probleem oplos deur skerp onderskeid te maak tussen die eksegese (filologies-grammatikaal en histories-literêr) èn die uitlegging (naamlik die teologiese soek na 'n sin), terwyl Haitjema geen teologiese gehalte wil toeken aan die histories-kritiese en 'formgeschichtliche' werkwyse in verband met die inhoud van die Heilige Skrif nie. Vir hom is hierdie metode nie teologiese arbeid nie en vir die eintlike teologie irrelevant. (Kyk hieroor o a Heitjema se artikel 'Geloofskriticisme als metode der theologie' en $\mathrm{K} \mathrm{H}$ Miskotte se 'Opmerkingen over theologische Exegese', in Tromp et al 1934: 39-99.)

Tweedens moet ons egter opmerk dat in die loop van die eeuelange geskiedenis van die praktyk en metode van die eksegese, tog verskillende dinge in hierdie verband na vore gekom het wat ons,vandag ' $n$ duideliker insig gee oor die metodiese werkwyse, aard en taak van die eksegese. Hierdie dinge is die volgende:

3.2.1 Hoewel die waarheid, sin en waarde van ' $n$ bepaalde teks of groter Skrifgedeelte nie soseer in die oorgelewerde woorde lê nie, is die filologies-grammatiese, literêr-historiese metode by alle eksegese brood-noodsaaklik en moet dit met die grootste eerlikheid, selfbeheersing, vlyt en objektiwiteit, soos Th Mommsen dit eenkeer beskryf het, deurgevoer word terwyl dit van alle hulpmiddele soos die filologie, die semantiek, die sintaksis en die tekskritiese en literêr- en histories-kritiese metodes gebruik maak.

Die voordeel van hierdie metode is dat dit in diè sin objektief is, dat dit nie die resultaat van die ondersoek probeer beïnvloed nie. Dit is onder andere met hierdie metode (hoewel destyds 
gebrekkiger as vandag) dat die Reformatore in hulle eksegese hulle kon losworstel van die tradisionalisme van die Roomse Kerk. Hierdie metode is onmisbaar.

Maar indien dit in die sin objektief is dat dit probeer om nie vooraf die resultaat van die ondersoek te beïnvloed nie, wil dit nie sê dat dit -

- prinsipieël-metodies vooronderstellingloos is nie, èn

- dat die ondersoeker in die toepassing van die metode nie beïnvloedbaar is nie.

Eerstens het dit prinsipieel-metodies die voorveronderstellinge van die wetenskappe waaruit dit groei, byvoorbeeld die filologie en geskiedenis en hierin kan selfs verskillende skole wees sodat as skool 'a' gekies word en nie ' $b$ ' nie, dit invloed op die verloop en resultaat van ' $n$ bepaalde ondersoek mag hê. Voordeel is egter dat hierdie metode (soos geen ander) die resultaat van die ondersoek die minste sal beïnvloed. Die eksegeet moet egter welbewus wees dat ook hier keuses gedoen word, byvoorbeeld tussen filologiese skole. Selfs by die eenvoudige sintaksis en grammatika is daar 'keuses' soos byvoorbeeld wanneer 'n ingressiewe aoristus nie uit sy blote vorm blyk nie. Salig ook die eksegeet indien hy presies weet wat hy doen.

Dit bring ons tweedens by die feit dat hoewel hierdie metode metodies-prinsipieel 'n groot mate van objektiwiteit kan inhou, veral in dié sin dat dit nie vooraf die resultaat probeer beïnvloed nie, daar by die toepassing van hierdie metode allerlei persoonlike faktore 'n rol speel. Voorbeelde hiervan is die invloed van vroeëre konklusies, persoonlike insig, aanleg, ensovoorts. Indien dit nie so was nie, dan sou hierdie fases van eksegese eenkeer klaar gedoen gewees het (en net so nou en dan by die ontdekking van nuwe materiaal aangevul kon word). Met ander woorde, dan sou ons ' $n$ onfeilbare teks met onfeilbare grammatikale eksegese kon hê. Daar moet altyd onthou word dat daar by die keuse van ' $n$ bepaalde lesing en by die keuse van verskillende grammatikale moontlikhede en by die keuse uit 'n klomp skakeringe en betekenisse van een enkele woord, meer as een moontlikheid is. En dit lê nie net by die beperktheid van die mens se verstand nie, maar by die saak self, naamlik by wat ons vroeër genoem het: Die menslike vorm waarin die Woord van God tot ons gekom het en kom. 
Die Kerk het hierdie metode en arbeid nodig met die oog op die prediking van die kerk. Die Kerk wil weet: 'Wat staan daar geskrywe?' Daarom kan die Kerk verwag dat hierdie historiesgrammatikale en literêre werk vir die Kerk met alle beskikbare hulpmiddels tot die einde toe gevoer moet word. Maar die Kerk mag ook verwag dat die eksegeet bewus sal weet dat hoewel die metode baie objektief is, daar by die toepassing van die metode ander faktore as die objektiwiteit van die metode ' $n$ rol speel, soos byvoorbeeld in die keuses van ' $n$ bepaalde tekslesing of van ' $n$ bepaalde woordbetekenis of van ' $n$ bepaalde grammatikale of sintaktiese moontlikheid. Op hierdie stadium kan die Kerk nie eis dat in hierdie keuse die leer van die Kerk die keuse en uiteindelike resultaat moet bepaal nie. Die Kerk kan nou nog hoogstens sê dat die eksegeet bewus moet wees dat dit selfs op hierdie stadium moontlik is dat die kerkleer of ' $n$ bepaalde wysbegeerte, ensovoorts 'n rol kan speel. 'n Konsekwensie hiervan is dat die eksegeet in hierdie stadium eerstens nie sal kan sê dat sy interpretasie en die Woord van God ident is nie en tweedens sal hy ook hier geen finale uitspraak mag doen en daarby hardnekkig soos die hairesis en die hairetikós bly staan nie. Doen die eksegeet dit, alreeds op hierdie beginstadium van sy arbeid, dan is hy nie besig met Dogmatiek nie, maar met voorskrywing van die dogma self en dan kan die Kerk met reg ernstig beswaar teen so 'n werkwyse hê; want al wat die Kerk op hierdie stadium vra, is: 'Wat staan daar geskrywe, histories en grammatikaal?' Indien die eksegeet hier sou wou ophou, dan sal hy kwalik, ná die stel van die moontlikhede, één kon kies, want keuse sou al vooronderstelling veronderstel. Derdens sal die Kerk van die eksegeet op hierdie stadium kan verwag dat hy sal weet dat, alhoewel hierdie werkmetode onmisbaar is, dit beperk is en nooit ten volle tot die volledige verstaan van 'n woord of geskrif sal kan voer nie. Hierdie metode is wesenlik beperk en wie die sin van ' $n$ uitspraak met die suiwer filologiese metode wil vind, kom nie klaar nie.

3.2.2 Hiervoor is nodig ' $n$ tweede funksie van die eksegese, die tweede trap in die eksegetiese arbeid, naamlik die uitlegging, die hermeneuse (Vriesen), die fenomenologie (Schleiermacher, Van der Leeuw), das Verstehen (Wach, Dilthey), literêre kritiek (Van Selms) wat wil vasstel: Wat wil die skrywer sê?

Hierdie fase is nie te skei van die eerste nie, soos alreeds 
daaruit blyk dat dit in sekere sin óok histories-krities is omdat dit nou nie soseer die oorgelewerde woorde wil vasstel en wil nagaan nie, maar die sin, waarheid en waarde van die woorde en sinne in hulle verhouding tot die geestelike persoon en sy situasie waarin daar gespreek is. Soos iemand gesê het: Indien iemand sou sê eksegese is alleen maar, wat ons hierbo genoem het, die eerste fase, dan is dit reg indien so 'n iemand net sal onthou dat dit maar die eerste stap, die beginstadium is. Verder dat die tweede stap (wat ons dit ook al noem; byvoorbeeld divinasie, interpretasie of parafrase) noodwendig is vir die regte verstaan van die Skrif en dat daarsonder, die speelruimte van misverstande oneindig groot is.

In elk geval, hierdie tweede fase gaan oor die sinsvraag: 'Wat wil die skrywer nou eintlik sê?' Hier duik baie probleme op waarvan die volgende twee die belangrikste is:

(a) Dit is nie so maklik om $e$ mente auctoris te eksegetiseer nie. Dikwels is daar meer as een outeur, byvoorbeeld in die sin dat die bepaalde Skrifgedeelte redaksies beleef het en die oorspronklike woorde en inhoude in 'n bepaalde literêre, formgeschichtliche patroon ingeweef is. Die vraag is nou: Uit watter auctor se mens moet nou ge-eksegetiseer word - dié van die oorspronklike auctor of vanuit die teenwoordige verband en is dit prinsipieel moontlik? Ook die wyse waarop die Nuwe Testament (byvoorbeeld Paulus) die Ou Testament eksegetiseer, kan nie as norm geld nie. Eerstens alreeds omdat ons daar in die Nuwe Testament nie sonder meer 'n eenduidige tipe eksegese van die $\mathrm{Ou}$ Testament het nie, alhoewel ons moet toegee dat hierdie eksegese van groot hulp vir die hedendaagse eksegese kan wees.

(b) Die tweede probleem is dat hierdie soek na die sin van 'n bepaalde Skrifwoord of -woorde waarin ons die saak wat die skrywer wil meedeel, wil begryp, baie meer as die eerste fase met persoonlike insigte en daarom met ' $n$ mate van subjektiwiteit en onsekerheid te doen het. En tog is hierdie fase van eksegese nodig omdat die Kerk daarsonder net so min kan klaarkom as sonder die filologiese metode wat ons hierbo as die 'eerste fase' van eksegese beskryf het.

Wat kan die Kerk hier vra? Ons glo twee dinge: Eerstens dat die eksegeet hom baie deeglik bewus sal moet wees van die mate 
van subjektiwiteit en alhoewel dit onmoontlik is om dit (die subjektiwiteit) uit te skakel, die eksegeet hom liewer deur 'Bybelse subjektiwiteit' as deur filosofiese, en andere subjektiwiteit sal laat lei. Tweedens dat die eksegeet bereid sal wees om die resultate in hierdie verband aanhoudend te hersien en sal besef dat die gesag van sy resultate hierdeur baie beperk word. Hier blyk veral dat eksegetiese uitsprake nie sonder meer Skrifuitsprake is nie.

Die derde fase van eksegese is dié fase wat vanaf die spreke van die auctor secundarius (of auctores secundarii) wil deurdring na die bedoeling van die Auctor Primarius, naamlik God. Hierdie stap behels dat ons vanaf die mensewoord, van wat die skrywer sê, sal probeer deurdring na die Gods Woord, want wat God sê, dit is vir die kerk van eintlike betekenis - dit is trouens die hele doel van die eksegese of anders het dit geen teologiese gesigspunt of teologiese funksie nie. Hier word van die veronderstelling uitgegaan dat die Bybel as Godsopenbaring ons in die vorm van menslike Skrifwoorde die Gods Woord self wil meedeel. Met ander woorde, hier staan ons voor die verband van Woord en Gees, van Skrif en Testimonium Spiritus Sancti, waarop ons al vroeër gewys het.

Om hierdie taak van deurdringing tot die Gods Woord via die Skrifwoord te volvoer, is eerstens nodig dat hierdie bepaalde Skrifwoord in sy verband gesien sal word met die geheel van die Bybelboodskap, veral dié dele wat direk op die bepaalde saak betrekking het.

Drie dinge dien hier opgemerk te word:

Eerstens: Dat hier, baie meer as by die twee vorige fases van die eksegese, die 'subjektiewe faktore' 'n rol sal speel. Weer eens kan die Kerk vra dat die eksegeet deeglik van sy eie subjektiwiteit bewus moet wees en die Kerk kan ook vra dat in die soek na samehang van een gedeelte met die res van die Bybel, die eksegeet ook op vorige derglike eksegetiese samehange, deur Kerk daargestel in sy dogma, sal let as één van die moontlike samehange, hoewel vir die eksegeet nie noodwendig die enigste samehang nie.

Tweedens: Dit moet besef word dat in hierdie soek na samehang, daar nie 'n metode uit die hemel geval het, 'n 
metode van die Heilige Gees nie. Ook hierdie arbeid is menslike werk, 'n menslike waagstuk en die enigste wat ook hier gedoen kan word, is dat daar gebid en gehoop kan word dat die Gees ons in alle waarheid sal lei. As mensewerk sal ook hierdie arbeid, en veral hierdie arbeid, ' $n$ baie voorlopige karakter dra. Maar juis vanweë die aard van hierdie werk sal ook besef moet word dat God die Heilige Gees nie ' $n$ dieper, ander en magiese $\sin$ in die woorde van die skrywers gelê het, wat hulleself nie kon ken of begryp nie. Anders sou daar 'n Testimonium Spiritus Sancti buite die Skrif om wees. Dit kan nooit as metodiese prinsiepe van die eksegese geld nie en hier lê trouens die grens van die allegoriese metode.

Hierdie 'subjektiewe' karakter het eksegete daartoe gebring om te beweer dat hierdie soort eksegetiese arbeid bokant die normale taak van die eksegese uitgaan, en soos die Rooms-Katolieke sê: Alleen by die kerklike leeramp tuishoort en deur hulle volbring kan word. Tereg is opgemerk dat die Protestant hierdie weë nie kan volg nie. Die eksegeet moet ook kan sê: Wat sê die Auctor Primarius? Wat sê God?, want anders is sy wetenskap nie teologie nie, maar blote filologie en fenomenologie.

Derdens: Dit is ook duidelik dat hier sprake is van wyere verbande, van leer, al is dit dan net insoverre as wat 'leer' in die Bybel self aanwesig is. Trouens die Kerk se leer wil ook nie iets anders sê en leer as wat die Bybel leer nie.

Hier vind ons die oorgang na die Sistematiese Teologie, na die Theologia Biblica en Dogmatica. Dit kan aangevoer word dat dit buite die bevoegdheid van die eksegeet om gaan. Hierteenoor kan die vraag gestel word: Is dit dan nie die taak van die eksegeet om deur die mensewoord tot die Gods Woord deur te dring nie? En, as hy as die vakman in hierdie proses nie die verbande lê nie, wie sal dit dan anders doen? 


\section{EKSEGESE EN DOGMA}

Die kerklike dogma wil (in Protestantse sin) niks anders wees as kerklike eksegese oor die hoofpunte van die Christelike geloof nie. In 'n sekere sin is daar ook binne die Protestantisme ' $n$ offisiële eksegese, naamlik die dogma van die Kerk. Maar aangesien dit oor die hoofpunte van die Christelike leer handel, is dit beperkter in omvang as die eksegese van die hele Skrif deur 'n eksegeet. Hierdie offisiële eksegese, die dogma, is in Protestantse sin prinsipieel net so subjektief en voorlopig as dié van die individuele eksegeet. Daarom moet die Protestantse Kerk die moontlikheid van hersiening, die moontlikheid van 'n gravamen vanaf die individuele eksegeet ooplaat. Hierdeur is die moontlikheid van 'n botsing tussen eksegese en dogma oopgelaat. Van sy kant moet die individuele eksegeet hierdie moontlikheid aksepteer en net soos die Kerk bereid wees om gekorrigeer te word. Ook hy mag nooit sy resultate sonder meer gelykstel met die Gods Woord nie. Hy moet erken dat albei, eksegese en dogma, menslike interpretasie en daarom feilbaar is. Maar indien hy, nadat hy, ná hierdie drie fases van eksegese deurloop het, sê: 'só sê Gods Woord' en die Kerk weer na ernstige en soortgelyke studie van die Skrif sê: 'nee, só sê die Gods Woord' en nie een van die twee partye kan oortuig raak nie, dan is daar nie net die moontlikheid nie, maar die werklikheid van ' $n$ botsing. In hierdie verband moet die eksegeet onthou dat die kerklike dogma alleen deur die Kerk gewysig kan word.

Ons insiens is dit prinsipieel moontlik dat die eksegeet in botsing kan kom met die leer van die Kerk, gesien hierdie drie fases van eksegese, want die eksegeet sê: 'So sê die Gods Woord' en die Gods Woord is ook die enigste gesag, bron en norm in die Kerk. Twee voorbeelde sal genoegsaam wees om hierdie punt te bewys:

(a) In die dae van Calvyn het Erasmus voluit die Godheid van Christus bely en volmondig saamgestem met die kerklike dogma op hierdie punt. Hy het egter Filippense 2:6 en ander Skrifgedeeltes wat op hierdie punt betrekking het, so verklaar asof hulle geen betrekking op hierdie punt van die Godheid van Jesus Christus het nie. Calvyn het toe gevra: Maar wat help my sogenaamde ortodokse belydenis indien my geloof geen grond en outoriteit in die Skrif het nie? (Calvin 1921: 56).

(b) Tweedens het ' $n$ hedendaagse teoloog verklaar: 'Want ' $n$ beskouing oor God wat nie in alle dele afhanklik is van wat die Kerk in die Skrif gevind het nie, mag onder ons geen verblyf vind nie...' (Van Selms 1952: 129). 
Omdat albei, die eksegese van die individu èn van die Kerk sê: 'Só spreek die Here', daarom is ' $n$ botsing nie uitgeslote nie, en kan ' $n$ eksegeet, indien hy by sy gevonde standpunt bly, dwaal.

\section{EKSEGESE EN DOGMATIEK}

Dit is nie die Dogmatiek, wat 'n wetenskap is, wat die dogma vorm en bely nie. Die dogma word gevorm en bely deur die Kerk. Wat word in die Dogmatiek gedoen? Of anders: Wat is die taak van die dogmatikus?

Ons antwoord is dat hy metodies feitlik op dieselfde wyse werk as die eksegeet (soos hierbo uiteengesit). Al verskil is dat sy objek van ondersoek nie primêr die Heilige Skrif is nie, maar die belydenis en leer van die Kerk. Metodies is hy in hierdie arbeid net so vry en net so gebonde as die eksegeet. Ook sy resultaat mag net so min beïnloed word deur vooroordeel (ook deur dogmatiese vooroordeel) as dié van die eksegeet. Die eerste en vernaamste taak van die dogmatikus is om vas te stel: 'Wat sê, leer en bely die Kerk?' Hy vra ook: Bely die Kerk, indien die Kerk só bely, reg? Dit wil sê, in ooreenstemming met Gods Woord? Indien hy vind dat dit nie reg is nie, dan sal hy, by wyse van ' $n$ gravamen na die Kerk toe moet gaan vir oorweging en beslissing.

Dit is egter nie sy prerogatief nie. Ook die eksegeet kan, indien daar botsing is, gaan.

In sy arbeid (wat hierbo sy tweede taak genoem is) maak die dogmatikus dus noodwendig (en dankbaar) gebruik van die resultate van dieeksegese.

Formeel is daar egter geen verskil in metode tussen eksegeet en dogmatikus nie. Voor albei lê die moontlikheid van botsing met die leer van die Kerk.

\section{OPSOMMING}

As opsommende konklusie kan ons ná bogenoemde nou stel: Die eksegeet (wat net soos die ander teoloë in diens van die Kerk en die prediking staan) het net soos die ander teoloë gelyke vryheid en gelyke gebondenheid, hoewel hy en die dogmatikus baie meer direk staan in verband met ' $n$ botsing tussen gevonde resultaat en kerklike dogma as die ander teoloë. Die vryheid van die teoloog (ook die eksegeet) lê in sy wetenskaplike metode wat sover as moontlik objektief moet wees ten opsigte van die resultaat van sy ondersoek. Dit beteken onder andere 
dat die resultaat van die eksegese nie vantevore alreeds deur die veronderstellinge vas staan nie. Sy gebondenheid is tweërlei: Aan die begin en aan die einde.

Aan die begin is hy nie vry ten opsigte van sy uitgangspunt nie. Sy objek van ondersoek is die Heilige Skrif en daarmee die veronderstelling: God spreek in die Heilige Skrif. In hierdie verband kan die Kerk hoogstens vra dat hy as lidmaat sal glo en dat hy op versoek van die Kerk ook die dogma van die Kerk, wanneer dit by die oorweging van wyere samehange kom, as één van die moontlikhede sal oorweeg. Dit gebeur dan ook dat 'n eksegeet hom in sy keuse van ' $n$ bepaalde moontlikheid van eksegese laat lei deur ' $n$ bepaalde stuk kerkleer (eksegese deur die Kerk) byvoorbeeld dat hy kies teen Sabellianisme of Arianisme. Eksegetiese prinsiepe is dit egter nie.

Aan die einde is hy weer gebonde, naamlik wanneer sy resultaat nie klop met dié van die kerkleer nie. Dan moet hy by wyse van gravamen (of op watter wyse die Kerk ook al so 'n 'strydigheid' behandel) bereid wees om die strydigheid uit die weg te ruim. In hierdie sin is die eksegetiese bedryf altyd 'n waagstuk. Dit sou geen waagstuk gewees het indien die laasgenoemde gebondenheid nie bestaan het nie.

\section{Literatuurverwysings}

CALVIN, J 1921. Commentaries on the Epistles of Paul the apostle: Philippians, Colossians and Thessalonians. Translated by J Pringle. Edinburgh: Calvin Translation Society.

DENZINGER, H 1953. Enchiridion Symbolorum, Index Systematicus. (Ed 29). Freiburgi: Herder.

KATOLIEKE KATECHISMUS 1941. Oudshoorn: Pallotti.

TROMP, D 1934. Openbaring der verborgenheid. Baarn: Bosch en Keunig.

VAN DER LEEUW, G 1954. De Bybel. Amsterdam: H J Paris.

VAN DER LEEUW, G 1958. Inleiding tot de Theologie. Amsterdam: H J Paris.

VAN SELMS, A 1951. Wie achter is, moet voorgaan. 's-Gravenhage: Boekencentrum.

VAN SELMS, A 1952. Lig uit Lig. Pretoria: HAUM.

W.A. = Weimar Ausgabe van Luther se Werke. Internasionaal gesiteer as: W.A. \& vol \& pag. 